\title{
A new data to distribution of Epilobium pseudorubescens A.K. Skvortsov (Onagraceae) in Poland
}

Ana Terlević \& Marcin Nobis

\begin{abstract}
A new data to distribution of Epilobium pseudorubescens A.K. Skvortsov (Onagraceae) in Poland. Acta Mus. Siles. Sci. Natur., 67: 63-66, 2018.

Abstract: Herbarium revision resulted in the finding of five new records of Epilobium pseudorubescens in Poland. The distribution map of the species is provided.
\end{abstract}

Key words: Epilobium pseudorubescens, distribution, Poland

\section{Introduction}

Epilobium pseudorubescens A. Skvortsov (Onagraceae) was described from Finland (with paratypes from Sweden and Russia) by Skvortsov (1995), and now is regarded as an invasive alien species in Eurasia. It probably has North American origin and it is closely related to E. adenocaulon Hausskn., an invasive alien species widely distributed in Eurasia (Skvortsov 1995). Epilobium pseudorubescens is usually treated as a synonym of E. ciliatum s. lato, but at least two separate taxa from this group are known to occur in Eastern Europe, namely E. adenocaulon and E. pseudorubescens. Although some authors find Finland to be a starting point of E. pseudorubescens spread into other areas of the Old World (Vinogradova et al. 2009), it is not excluded that it could be accidentally introduced to other areas of Europe and Asia at more or less the same time, from which it could spread further. Seed propagation by anemochory probably contributed to a wide and relatively rapid dispersal of E. pseudorubescens in Eurasia. This species is invading not only various anthropogenic communities, but also quite successfully penetrates some natural phytocenosis (Ebel 2013). To date, Epilobium pseudorubescens has been recorded from Sweden, Finland, Russia, Ukraine, Belarus, Poland and some other Baltic countries (Seregin 2012).

The most evident characteristic that differs E. pseudorubescens from E. adenocaulon is the colour of corolla petals, that are white vs. pink, respectively. Furthermore, E. pseudorubescens usually has light green leaves with well-defined petioles (instead of darker green leaves with red pigmentation) and the leaf blade is the widest in the middle part, whereas in E. adenocaulon it is closer to the base of the leaf. The differences between these two species are particularly noticeable when they grow together within the same area (Ebel 2013).

Tzvelev (2007) relates E. pseudorubescens to the section Glandulosa Tzvel. In appearance, E. pseudorubescens is also somewhat similar to the less related species E. roseum Schreb. (section Synstigma Hausskn. ex Raimann), however differs from the latter by the distribution and density of trichomes on stem, inflorescence axes, calyx and ovaries and on spindle-shaped seeds, as well as by seed micromorphology (presence of an appendage on the tip of the seed, surface of the seed with conspicuous longitudinal white stripes, which are rows of laterally compressed and fused ridges of epidermal cells; Seavey et al. 1977).

First records of Epilobium pseudorubescens from Poland have been given by Seregin (2012), based on the herbarium specimens preserved in the herbarium of the Warmia-Mazury University in Olsztyn. The aim of our study was to update the distribution map of E. pseudorubescens in Poland, based on our findings from the revision of herbarium materials preserved at the Herbarium of the Institute of Botany of the Jagiellonian University in Kraków. 


\section{Materials and methods}

The herbarium material of Epilobium deposited in the Herbarium of the Institute of Botany, Jagiellonian University in Kraków (KRA) was revised in 2018. Altogether, around 500 herbarium sheets of Epilobium were revised and among them, five specimens corresponding with the description of E. pseudorubescens have been found. Information about previously known records of this species in Poland was obtained from Seregin (2012), and these localities were presented on the distribution map (Fig. 1).

\section{Results and Discussion}

Herbarium revision revealed five new localities of E. pseudorubescens in Poland (Fig. 1).

1. Poland, sad wiśniowy [cherry orchard near Sienno], FE4021 (2.5 x 2.5 km), 1 Jul 2002, R. Piwowarczyk (KRA 355089) [determined originally as E. ciliatum];

2. Poland, Kaszuba, przydroże [Kaszuba vill., roadside], 5356'38"N/17³9'03"E, CB34, 26 Jul 2006, K. Kozłowska (KRA 302889) [determined originally as E. ciliatum];

3. Poland, Niecka Połaniecka (Wyżyna Małopolska), Granicznik, nieużytek porolny [Polaniecka Basin, Granicznik, fallow], EF0933 (2.5 x 2.5 km), 10 Aug 2009, A. Pieścinska (KRA 436645) [determined originally as E. ciliatum];

4. Poland, Biała, rów przy szosie [Biala, dich by the road], FF7403 (2 x 2 km), K. Oklejewicz, 23 Sept 2011, (KRA 451081) [determined originally as E. ciliatum];

5. Poland, Lubienia, forests roadside, ca $5 \mathrm{~km} \mathrm{NE}$ of the village, $51^{\circ} 04^{\prime} 28^{\prime \prime} \mathrm{N} / 21^{\circ} 15^{\prime} 28^{\prime \prime} \mathrm{E}$, EE5803 (2.5 x 2.5 km), 25 Jul 2015, M. Nobis (KRA) [determined originally as E. pseudorubescens].

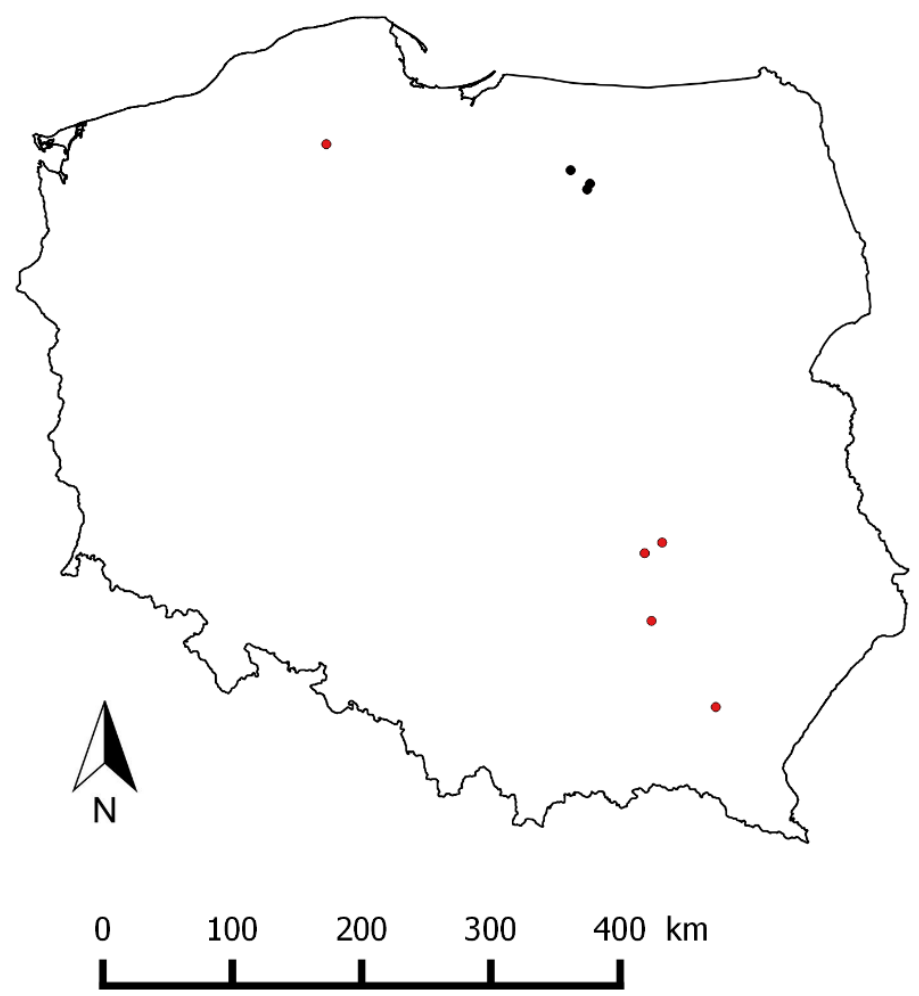

Fig 1: Distribution of Epilobium pseudorubescens in Poland, $\bullet-$ previously known locality, $\bullet-$ new record.

Although the colour of corolla is mentioned as the most distinct character that differs E. pseudorubescens and E. adenocaulon, morphologically they are very similar. It cannot be excluded that specimens with white corolla may represent only a variability of E. adenocaulon. Thus, for establish the relationship between these two, mentioned above taxa, further studies employing both morphological and molecular methods are needed. 


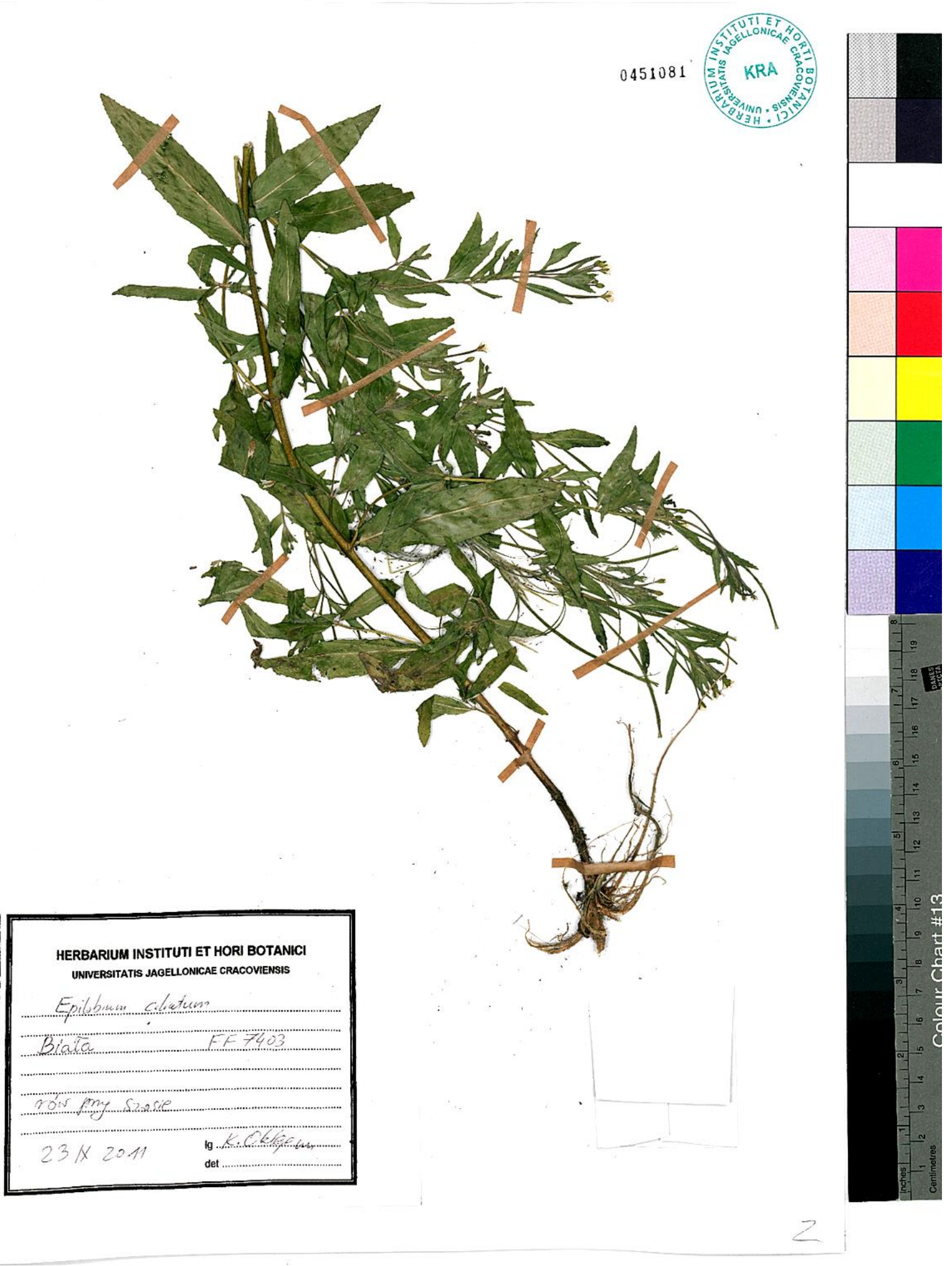

Fig 2: Herbarium sheet with specimen of Epilobium ciliatum collected by K. Oklejewicz in 2011 (KRA 451081). 
Acknowledgements: The research was finantially supported by Institute of Botany at the Jagiellonian University (K/ZDS/007344).

\section{References}

Ebel A.L. (2013): On the distribution of Epilobium pseudorubescens (Onagraceae) in Siberia. - Turczaninowia 16(3): 112-115.

Seavey S.R., Magill R.E. \& Raven P.H. (1977): Evolution of seed size, shape and surface architecture in the tribe Epilobieae (Onagraceae). - Ann. Missouri Bot. Gard. 64: 18-47.

Seregin S.P. (2012): Epilobium pseudorubescens A.K. Skvortsov (Onagraceae), a new invasive alien for the Polish flora. - Byull. Moskovsk. Obshch. Isp. Prir., Otd. Biol.117(3): 81-82.

Skvortsov A.K. (1995): Taxonomy and nomenclature of adventive Epilobium species in Russia. - Byull. Moskovsk. Obshch. Isp. Prir., Otd. Biol. 103(1): 74-78.

Snogerup S. (2010): Epilobium L. In: Jonsell B. \& Karlsson T. (eds): Flora Nordica. 6: 91-131. Thymelaeaceae to Apiaceae. Stockholm.

Szafer W. \& Pawłowski B. (eds) (1959): Flora Polska: Rośliny Naczyniowe Polski i Ziem Ościennych. 8: 428. Warszawa.

Tzvelev N.N. (2007): On the genus Epilobium L. (Onagraceae) in Eastern Europe. - News sist. supreme. 39: 241-259.

Vinogradova Yu.K., Mayorov S.R. \& Khorun L.V. (2009): Chernaya kniga flory Srednei Rossii (Chuzherodnye vidy rasteniy v ekosistemakh Sredney Rossii). Moscow, 494 pp (web-version: www.bookblack.ru).

Authors' addresses: Ana Terlević \& Marcin Nobis, Institute of Botany, Faculty of Biology, Jagiellonian University, Gronostajowa 3, 30-387 Kraków, Poland.

corresponding author: m.nobis@uj.edu.pl 